\title{
ANALYSIS OF CONCENTRATED SOLAR POWER TECHNOLOGIES' FEASIBILITY, SELECTION AND PROMOTIONAL STRATEGY FOR BANGLADESH
}

\author{
Amit Barua $^{1 *}$, Sanjib Chakraborti $^{2}$, Dabajit Paul ${ }^{3}$, Prasanjit Das $^{4}$ \\ ${ }^{1}$ Dept. of Industrial \& Production Engineering, Bangladesh University of Engineering \& Technology, Dhaka \\ ${ }^{2}$ Technical Consultant, Go for Green, Sweden \\ ${ }^{3}$ Rangs Workshop Ltd, Tejgaon Industrial Area, Dhaka \\ ${ }^{4}$ Department of Mechanical Engineering, Chittagong University of Engineering \& Technology, Chittagong \\ "Corresponding e-mail: amitbarua15@gmail.com
}

\begin{abstract}
Bangladesh gets solar radiation of average 4-6.2 $\mathrm{KWh} / \mathrm{m}^{2} /$ per day that shows a great opportunity for all types of solar power generation technologies ranging from small to large scale. However, solar power technology is confined in only Photovoltaic (PV) technology though it deserves ideal condition for concentrated solar power (CSP) technologies of power generation. Accounting the limited source and depletion of fossil fuel as well as foreign currency that expense for imported oil, adaptation of CSP technology can brings a solution of future sustainable and cheap source of power. This research has analyzed existing developed CSP technologies and their comparative characteristic. A study has been conducted to find out feasibility of CSP technology implementation and selection of suitable CSP plant for Bangladesh. The findings of this study can be helpful to formulate policies support tools to take into account the future solar energy and sustainable utilization, promotion and development for CSP technologies.
\end{abstract}

Keywords: Solar Energy, Renewable Energy, Concentrated Solar Power (CSP), Energy Policy.

\section{INTRODUCTION}

At present, Bangladesh has energy supply from both renewable and nonrenewable sources. The main renewable energy comprises of biomass, biogas, solar, hydro, wind, wave energy. This country is fully depends on natural gas, imported oil and biomass to meet energy demand. Present electricity coverage in Bangladesh is only $62 \%$ of total area and per capita electricity consumption is about $321 \mathrm{KWh}^{1}$. Electricity generation is $6000 \mathrm{MW}$ average against demand of 7500 MW while the demand for electricity has been rising by 10 percent every year. In the year 2014 fuel mix for electricity generation is as follows: coal (1.92\%), hydro (2.12\%), natural gas (64.78\%), Diesel (7.32\%), Furnace Oil (19.04\%) and imported (4.81\%) [1]. The government buys electricity from oil based rental power plants at high rate and provide subsidy supplying electricity to the consumers at an acceptable rate. For this reason, economy of Bangladesh has fallen in acute crisis. Beside shortage of natural gas is creating a shortfall of electricity about $1500 \mathrm{MW} /$ day [1]. This wide gap between production and demand is mainly due to shortage for gas, high speed diesel (HSD), heavy fuel oil (HFO) and hurting the power sector. Due to geographical position, Bangladesh has about 300 clear shiny days with solar radiation of average $5 \mathrm{KWh} / \mathrm{m}^{2} /$ per day that shows a huge prospect for CSP plants ${ }^{2}$. Having abundance resource of solar energy, until now there is limited uses of solar energy in scientific way. Uses of solar energy mainly confines in only solar PV home application. Government has taken a policy to meet 5 percent of the country's energy demand through green energy by 2015 and 10 percent by $2020^{3}$. To achieve this target CSP plants can play a vital role due to availability of solar radiation and it is higher than any other renewable energy resources in addition without threatening environment. Bangladesh is losing at least $3.5 \%$ of Gross Domestic product (GDP) due to the shortage of power supply according to a research report of Centre for Policy Dialogue $(\mathrm{CPD})^{4}$. In future CSP technologies can supersede the conventional energy sources as power crisis is acute also uncertainty of fuel sources. CSP plants can compensate shortage and increase generation of power furthermore reduces carbon dioxide emissions. This research has analyzed existing CSP technologies along with their opportunity, selection criteria of suitable technology and promotional strategy for Bangladesh.

\section{CONCENTRATED SOLAR POWER (CSP) TECHNOLOGIES}

Concentrating solar power (CSP) technologies are based on the direct use of solar radiation that concentrated into a smaller area. Concentrating solar collectors can achieve temperatures in the range of $300^{\circ} \mathrm{C}$ to $1000^{\circ} \mathrm{C}$ or even higher, which is ideal for generating electricity via thermodynamic power cycles $^{5}$. This extreme heat is used to generate steam to drive large, conventional turbines or Stirling heat engines ${ }^{6}$. These technologies are relying on lenses and mirrors for concentration of ray. Recent advancements in production techniques, materials, particularly the development of cheap plastic Fresnel lenses have driven the costs of CSP technologies down to a remarkable competitive level with photovoltaic's as well as traditional power generation sources and other renewable technologies such as wind. CSP technologies are relatively expensive in operations and 
maintenance compare to PV systems but those possess thermal energy storage (TES) facilities also suitable to dispatch power in grid by hybridization with existing conventional generation system ${ }^{7}$. One long-term scenario foresees that by 2040 CSP's contribution would be at a level of almost 630000 MW (SER, $2004)^{8}$. CSP systems can easily use fossil fuels such as natural gas as a back up fuel. Numerous modern designs are equipped with heat storage system that allows dispatch of electricity smoothly in absence of sunlight $^{6}$. CSP technologies are also potential for various applications such as household cooking and small scale manufacturing industry. Four types of CSP technologies are being used in this world; they are parabolic trough, power tower, parabolic dish, Linear Fresnel Reflectors (LFRs) ${ }^{9}$. Among the all of the CSP technologies, parabolic trough technology is highly developed and it deserves the most commercial experience. Power tower technologies deserve high temperature producing facilities and require less land compare to parabolic trough. Moreover, the cost of manufacturing is relatively low because heliostats reflectors are nearly flat ${ }^{10}$. Parabolic dish technology offers the highest solar to electricity conversion capacity. Several features, including: the compact size, absence of cooling water, and low compatibility with thermal storage and hybridization put parabolic dishes in competition with PV modules, especially concentrating photovoltaic's (CPV), as much as with other CSP technologies. Linear Fresnel Reflectors (LFRs) will probably have lower energy conversion efficiency and may not have the high optical accuracy like dish and trough systems. It has the potentiality for lower capital and operating costs. It could produce energy cheaper than other solar thermal systems ${ }^{7}$. In Table 1 important characteristic of existing four CSP plants have been discussed.

Table 1. Comparison of the major features of the four main types of CSP technologies

\begin{tabular}{|c|c|c|c|c|}
\hline & Trough & Tower & LFR & Dish Engine \\
\hline Typical capacity (MW) & $10-300$ & $10-200$ & $10-200$ & $0.01-0.025$ \\
\hline Maturity of technology & $\begin{array}{c}\text { Commercially } \\
\text { proven }\end{array}$ & $\begin{array}{c}\text { Pilot commercial } \\
\text { projects }\end{array}$ & Pilot projects & $\begin{array}{c}\text { Demonstration } \\
\text { projects }\end{array}$ \\
\hline Operating temperature $\left({ }^{\circ} \mathrm{C}\right)$ & $350-550$ & $250-565$ & 390 & $350-750$ \\
\hline Plant peak efficiency $(\%)$ & $14-20$ & $23-35$ & 18 & 30 \\
\hline $\begin{array}{c}\text { Annual solar-to electricity } \\
\text { Efficiency (net) }(\%)\end{array}$ & $11-16$ & $7-20$ & 13 & $12-25$ \\
\hline Annual capacity Factor $(\%)$ & $\begin{array}{l}25-28 \text { (no TES) } \\
29-43 \text { (7h TES) }\end{array}$ & 55 (10h TES) & $22-24$ & $25-28$ \\
\hline Hybridization & Yes and direct & Yes & $\begin{array}{c}\text { Yes, direct } \\
\text { (steam boiler) }\end{array}$ & Not planned \\
\hline Cycle & $\begin{array}{c}\text { Superheated } \\
\text { Rankine steam } \\
\text { cycle }\end{array}$ & $\begin{array}{c}\text { Superheated } \\
\text { Rankine steam } \\
\text { cycle }\end{array}$ & $\begin{array}{l}\text { Saturated Rankine } \\
\text { steam cycle }\end{array}$ & Stirling \\
\hline Steam conditions $\left({ }^{\circ} \mathrm{C} / \mathrm{bar}\right)$ & 380 to $540 / 100$ & $540 / 100$ to 160 & $260 / 50$ & N/A \\
\hline Application type & On grid & On grid & On grid & $\begin{array}{c}\text { On-grid/Off-gri } \\
\mathrm{d}\end{array}$ \\
\hline $\begin{array}{c}\text { Storage with molten } \\
\text { Salt }\end{array}$ & $\begin{array}{c}\text { Commercially } \\
\text { available }\end{array}$ & $\begin{array}{c}\text { Commercially } \\
\text { available }\end{array}$ & $\begin{array}{c}\text { Possible, but not } \\
\text { proven }\end{array}$ & $\begin{array}{c}\text { Possible, but not } \\
\text { proven }\end{array}$ \\
\hline $\begin{array}{l}\text { Water requirement } \\
\qquad\left(\mathrm{m}^{3} / \mathrm{MWh}\right)\end{array}$ & $\begin{array}{c}3 \text { (wet cooling) } \\
0.3 \text { (dry } \\
\text { cooling) }\end{array}$ & $\begin{array}{l}2-3 \text { (wet cooling) } \\
0.25 \text { (dry cooling) }\end{array}$ & $\begin{array}{c}3 \text { (wet cooling) } \\
0.2 \text { (dry cooling) }\end{array}$ & $\begin{array}{c}\text { 0.05-0.1 (mirror } \\
\text { washing) }\end{array}$ \\
\hline
\end{tabular}

Source: International Renewable Energy Agency (IRENA, 2012) ${ }^{12}$

\section{COST OF CSP TECHNOLOGIES}

CSP technologies have some successes but installation costs are higher in comparison with conventional fossil fuel technologies. The current investment cost of CSP plants varies significantly by project size and solar resource. The current investment cost for parabolic trough and solar tower plants without storage are USD $4600 / \mathrm{kW}$ and USD $7500 / \mathrm{kW}^{12}$. CSP plants with thermal energy storage tend to be significantly more expensive but possess higher capacity factors, continuation of generation during absence of sun thus maximize generation at peak demand period. The cost of parabolic trough and solar tower plants with thermal energy storage are generally between USD 9800/KW and USD 10500/kW. Besides, per KW installation cost is about 8 to 10 times higher than conventional power plant. To understand the potentiality and future prospect of CSP technologies the cost of solar PV cell can be compared with the cost of parabolic trough and solar tower. According to Infrastructure Development Company Limited cost of solar PV panel with 4 to 5 hours backup system is USD 
$8000-9000 / \mathrm{KW}$ which is nearer to existing cost for parabolic trough with 6 hours storage and solar tower with 12 hours heat storage facilities. But investment in CSP power plant is feasible due to absence of fuel cost and long life cycle. Overall cost of power also depends on lands selection; infra structure development, transmission, communication system. CSP technology providers expected that by 2015 installation cost of parabolic trough and solar tower with thermal storage will be USD 8300 and USD 9000 respectively ${ }^{12}$. Many studies reveal that the cost of CSP technology remarkably parabolic trough and solar tower will reduce. It has been claimed that cost reduction will come from economies of scale of the plant size, manufacturing industry, learning effects, advances in R\&D, a more competitive supply chain and improvements in the performance of the solar field, solar to electricity conversion efficiency and thermal energy storage systems. By the year 2020 the following feature could achieve such as capital cost reduction from $28 \%$ to $40 \%$, economies of scale $21-33 \%$, efficiency increase $10-15 \%$, technology improvement $18-22 \%$ of present CSP plants respectively and even higher reductions may be possible ${ }^{13}$. To understand existing and future installation cost, capacity factor, operations and maintenance cost of CSP plants have given in Table 2 .

Table 2. Total installed Cost for Parabolic Trough and Solar Tower.

\begin{tabular}{|c|c|c|c|c|}
\hline & $\begin{array}{c}\text { Installed cost } \\
(2010 \mathrm{USD} / \mathrm{kW})\end{array}$ & $\begin{array}{c}\text { Installed cost } \\
(2015 \mathrm{USD} / \mathrm{kW})\end{array}$ & Capacity factor (\%) & $\begin{array}{c}\text { O\&M } \\
(2010 \mathrm{USD} / \mathrm{kWh})\end{array}$ \\
\hline Parabolic trough & & & & \multirow{6}{*}{0.02 to 0.035} \\
\hline No storage & 4600 & 3900 to 4100 & 20 to 25 & \\
\hline 6 hours storage & 7100 to 9800 & 6300 to 8300 & 40 to 53 & \\
\hline \multicolumn{4}{|l|}{ Solar tower } & \\
\hline 6 to 7.5 hours storage & 6300 to 7500 & 5700 to 6400 & 40 to 45 & \\
\hline 12 to 15 hours storage & 9000 to 10500 & 8100 to 9000 & 65 to 80 & \\
\hline
\end{tabular}

Source: International Renewable Energy Agency (IRENA, 2012) ${ }^{12}$

\section{PLANT PERFORMANCE}

Energy production is related to capacity, capacity factor and time. Energy produced over a period (MWh) = Capacity (MW) x capacity factor $\mathrm{x}$ time (hours). In the case of PV the capacity of electricity generation is based on its 'peak' value which is capacity. The use of storage or auxiliary fuel allows a higher capacity factor for the solar generation plant. For example: Capacity factor of parabolic trough and solar tower is $20-25 \%$ and $40-45 \%$ without storage. The capacity factor is increased with storage facilities.

\section{FEASIBILITY ANALYSIS OF CSP PLANT}

For smooth operations of CSP plant there is requirement of abundance direct solar radiation. Beside only strong direct sunlight can be concentrated to achieve the temperature required for power generation. From research it has been found that CSP plant with direct normal irradiance levels (DNI) of $2000 \mathrm{kWh} / \mathrm{m}^{2} /$ year or more are economic in operations. Therefore, DNI more than $5 \mathrm{kWh} / \mathrm{m}^{2} /$ day is required $^{7}$. The power generation potentiality of a CSP plant is largely determined by the DNI and it is determined by meteorological factors (e.g. cloud cover, humidity) and local environmental factors (e.g. local air pollution, dust). Tracking the sun can provide a significantly greater energy yield for a given DNI. Globally CSP plants are installed and led by USA, Spain and their average DNI are $2700 \mathrm{kWh} / \mathrm{m}^{2} /$ year and $2100 \mathrm{kWh} / \mathrm{m}^{2} /$ year respectively ${ }^{7}$. Similarly Bangladesh has convenient meteorological condition for efficient CSP plant operations along with many potential locations having annual DNI ranging from 1500 to $2300 \mathrm{kWh} / \mathrm{m}^{2}$. About $180 \times 109 \mathrm{Mwhr} /$ year electricity can be generated if solar radiation is 5 $\mathrm{kWh} / \mathrm{m}^{2} /$ day and it is 105 times the energy presently generated as electricity ${ }^{11}$. Necessary meteorological factors for CSP plants are given in Table 3. Mondal (2011) studied the potentiality and viability of grid connected of $1 \mathrm{MW}$ using RET screen simulation software for 14 widespread locations in Bangladesh and showed the favorable condition for the development of the PV systems in Bangladesh ${ }^{14}$. A successful model of $1.1 \mathrm{KW}$ solar PV systems was installed on the roof top of the Renewable Energy Research Center of Dhaka University in 2008.

Table 3. Meteorological factors of Bangladesh.

\begin{tabular}{|c|c|}
\hline Latitude & $\begin{array}{c}20.30-26.38 \text { degrees north } \\
\text { and } 88.04-92.44 \text { degrees } \\
\text { east }\end{array}$ \\
\hline Average temperature & 27 to 32 degrees \\
\hline Average rainfall & $2250 \mathrm{~mm}$ \\
\hline $\begin{array}{c}\text { Direct normal } \\
\text { irradiance (DNI) }\end{array}$ & 4 to $6.5 \mathrm{kWh} / \mathrm{m}^{2} /$ day \\
\hline $\begin{array}{c}\text { Daily Average of } \\
\text { Bright Sunshine }\end{array}$ & 7.55 Hours \\
\hline Average shiny day & 300 days \\
\hline
\end{tabular}

Source: Bangladesh Meteorological Department (2010) ${ }^{16}$

A techno-economic feasibility analysis was carried out for $100 \mathrm{~kW}$ PV grid systems by a simulation software Renewable Energy Technologies screen

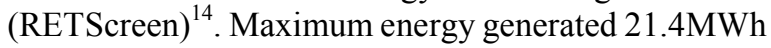


in April, minimum energy generated 11.32MWh in September, and annual total production is 148.475MWh. Per unit energy production cost found for the proposed project is 9.68 BDT, which was competitive with diesel-based grid power generation. Generally per unit electricity production cost was varying from 4.24 BDT to 14.00 BDT with the PV panel cost. According to this model $1 \mathrm{MW}$ electricity can be generated from roof top of forty buildings. This PV grid electricity generation system shows a good prospect that solar radiation is suitable for the grid connected solar power system. This study also shows a good prospect of CSP technologies that will commercially suitable for CSP plants with grid connected system. It had been found that the per unit electricity production cost from the grid connected PV system was competitive with grid-connected diesel power generation. Therefore, there is possibility of comparatively lower electricity production cost by using improved CSP technologies. Comparison of installation, operations and maintenance cost between parabolic trough and solar tower without storage have been shown in figure 1 .

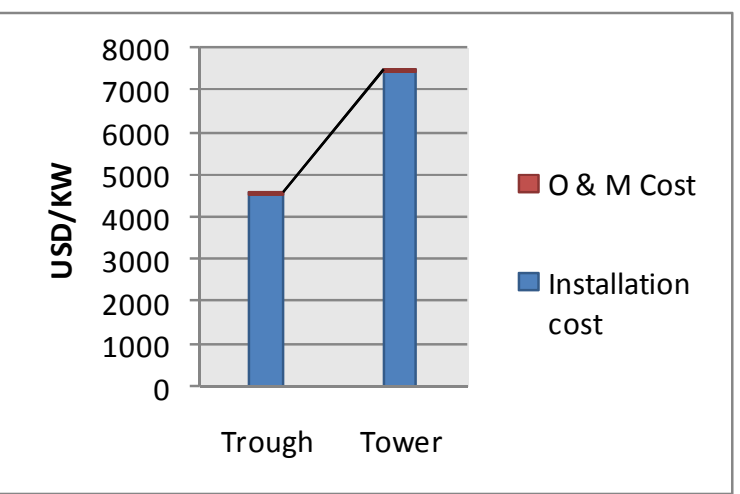

Figure 1. Cost comparison of solar Trough and Tower. Source: International Renewable Energy Agency (IRENA, $2012)^{12}$

All large power plants in Bangladesh are steam turbine and natural gas based. Most of the plants are easily combinable with parabolic trough technology and natural gas can be used as an auxiliary fuel to operate the combine cycle CSP plant the in absence of sun. Due to good solar radiation of $5 \mathrm{KWh} / \mathrm{m}^{2}$ and 360 shiny day's annual plant capacity factor of parabolic trough plant $25-28 \%$ will be according to rated value. Parabolic trough is a matured technology and commercially proven for more than 20 years. On the other hand solar tower technology is on pilot commercial projects stage. More than $80 \%$ of CSP projects currently in operations, under construction or development in the world are based on parabolic trough technology. Table 4 shows current CSP plants operating throughout the world.
Table 4. Current CSP projects in the world.

\begin{tabular}{|c|c|c|c|c|}
\hline & $\begin{array}{c}\text { Operat } \\
\text { ional } \\
{[\mathrm{MW}]}\end{array}$ & $\begin{array}{c}\text { Under } \\
\text { construct } \\
\text { ion MW] }\end{array}$ & $\begin{array}{c}\text { Planning } \\
\text { phase } \\
{[\mathrm{MW}]}\end{array}$ & Total \\
\hline Tower & 44 & 17 & 1603 & 1664 \\
\hline $\begin{array}{c}\text { Parabolic } \\
\text { Trough }\end{array}$ & 778 & 1400 & 8144 & 10322 \\
\hline Fresnal & 9 & 30 & 134 & 173 \\
\hline $\begin{array}{c}\text { Dish \& } \\
\text { Stirling }\end{array}$ & 2 & 1 & 2247 & 2250 \\
\hline Total & 833 & 1448 & 12128 & 14409 \\
\hline
\end{tabular}

Source: International Renewable Energy Agency (IRENA, 2012) $)^{9,12}$

\section{PROMOTIONAL STRATEGY}

Steps have been taken by the government to encourage mills and factories to install solar PV panel to meet certain percentage of their load demand from solar power. Nevertheless, this policy will be very challenging to utilize due to expensive solar panel and installation cost as well as no subsidy has been provided. Besides high electricity unit price for solar PV system and high maintenance charge above all lack of interest and this PV solar system is considered as hurdle. Solar PV system needs huge amount of land for installation as Bangladesh is a densely populated country there is shortage of available suitable lands for solar PV power plant in large scale besides urbanization and commercialization has made price of land very high. Installation of large scale solar PV power plants seems to be a greater concern for huge land requirement but this can slightly reduce by choosing convenient CSP plant. Therefore, it will be very effective if all large consumers of power gather together to install a central power plant and dispatch from a central substation. Power Division has aimed to install solar mini grid systems in off grid remote areas across the country. Similarly it will be very effective if mini grid can be built for industrial area or export processing zone (EPZ) and electricity can be dispatched through such type of mini grid that is generated from medium to large CSP power plant. CSP plants are proved technology to run combined with gas turbine power plant. There are many gas turbine based power plants in Bangladesh those are remaining shut down due to shortage of gas. By combine operation with CSP plant these gas turbine based power plants can bring in operation again. Government should let the foreign investors or companies to invest in CSP power plant on $100 \%$ foreign ownership basis or joint ventures with local company for financial or technical collaboration and to set up of solar power generation projects for future. Considering sun as future abundance single source of energy CSP plant should install on experimental basis. 


\section{CONCLUSION}

Various studies reveal that there are many potential locations for large scale solar power generation in Bangladesh. From the technical and environmental point of view it is observed that installation of CSP plant in Bangladesh can bring huge benefits than alone stand building roof top or solar PV system. It is a non oil producing country, recoverable gas reserve will deplete soon and the coal reserves will last for only the next few decades. Supply of nuclear fuel via uranium is governed by geopolitical and matter of high secured technology. Most of the developed countries are going to stop nuclear fuel based power plants. The government of Bangladesh has aim to provide affordable and reliable electricity to all citizens by 2021. Hence accounting all these matter and opinion of energy expert it can be said that in future solar energy will be the major source of energy. By installing and utilizing CSP technology in power generation present power crisis can mitigate without carrying huge burden of fuel cost and without threatening the environment. Till now CSP technologies are expensive to install and matter of sound technological knowledge. These CSP plants are cost effective only for large scale production. Nevertheless, a joint study of Greenpeace International, the European Solar Thermal Electricity Association, and the International Energy Agency's Solar PACES group investigated that the production cost per unit of power from CSP plants will be cheaper than power from coal fired plant by 2015 due to efficiency improvements and mass production of equipment [15]. Considering the social, environmental reservation responsibilities government as well as private entrepreneurs can step forward to install CSP plant in this country to ensure sustainable energy source and keep the growth of industrialization, projected GDP in this country. The government should be more sincere, invest more and provide incentive for research and development of solar power technologies. Finally it is suggested that government can take into account above mentioned promotional strategies for CSP plant to fix any policy and parabolic trough is suitable for Bangladesh. Besides considering land utilization, future cost reduction; solar tower power plant should be in second option.

\section{REFERENCES}

1. Bangladesh Power Development Board, 2014 http://www.bpdb.gov.bd/

2. S. Huque, R. K. Mazumder, 2006, "A concentrator PV power system in water pumping", National Seminar on Renewable Energy: Biomass/Bio Energy, Dhaka, 24th March, pp 65-70.

3. Ministry of Energy and Mineral Resources, 2014.

4. N. Rahman, 2009, "A Solar Dream”, Star Magazine, the Daily Star, Dhaka, vol. 17, pp 9.

5. "Survey of Energy Resources, 2007”, Solar Energy, World Energy Council, vol. 21, pp 389.

6. B. D. Chiaro, S. Payne, T. Dutzik, 2008, “On the rise: Solar Thermal Power and the fight against global warming", Environment America Research and Policy Center, pp 13.

7. S. Grama, E. Waymen, T. Bradford, 2008, "Concentrating Solar Power -Technology, Cost and Markets", Prometheus Institute for Sustainable Development and Greentech Media, Cambridge, USA, pp 13-35, 63-78. 8. "Survey of Energy Resources (SER)-2004", World Energy Council, Oxford, UK.

9. "Technology Road map concentrated solar power plants", 2010, International Energy Agency, pp 4-7.

10. E. Kins, W. Harland, M. Andrew, 2009, "Large-scale roll out of concentrating solar powr in South Africa", Engergy Research Center, University of Cape Town (UCT), South Africa, pp 3.

11. Zaman M., Islam M. A., Sarkar M. A. R. 2006 , "Two Phase Heat Transfer in Solar Water Heater", National Seminar on Renewable Energy: Biomass/Bio Energy, Dhaka, 24 ${ }^{\text {th }}$ March, p 32- 36.

12. "Concentrating Solar Power", 2012, Renewable Energy Technologies: Cost Analysis Series, Vol.1, Power Sector Issue 2/5, June, International Renewable Energy Agency, pp 26-29.

13. J. Hinkley, 2011, “Concentrating Solar Power -Drivers and Opportunities for Cost-competitive Electricity ", CSIRO, Victoria, pp 10-17.

14. M. A. H. Mondal, A. Islam, 2011, "Potential and viability of grid connected solar PV system in Bangladesh", Renewable Energy, vol. 36, pp.1869-1874.

15. S. Teske, R. Aringhoff, G.Brakmann, 2011, "Exploiting the heat from the sun to combat climate change", European Solar Thermal Electricity Association, Greenpeace International and the International Energy Agency's, Solar PACES, pp 4.

16. Bangladesh Meteorological Department, 2010, http://www.bmd.gov.bd 